\title{
State of the Academy
}

\section{6}

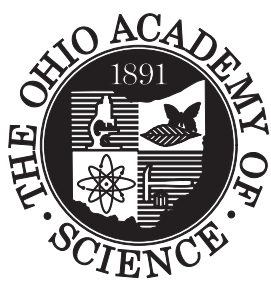

It's amazing how quickly the year has ended and how rapidly we need to prepare for a busy 2017. The Ohio Academy of Scienceis grateful to its members, volunteers, and sponsors for making State Science Day, Buckeye Science and Engineering Fair, Annual Meeting, OEEF Scholarships, Melvin Scholars, Thomas Edison Awards and of course, The Obio Journal of Science all possible. Whether your contribution sponsored an event or you served as a referee, judge, reviewer, or mentor, thank you for supporting science and science education in Ohio.

Invention Convention - A record number of students participated in the 2015-2016 school year. More than 8,000 students completed the program and approximately 900 students went on to qualify for one of the three regional competitions held in Northeast Ohio, Central Ohio, and Southwest Ohio; and for the first time, 73 students went on to represent Ohio at the National Invention Convention and Entrepreneurship Expo in Washington D.C. This was more than any other state!

In November, 2016, the Academy announced that the Invention Convention will no longer be operated as an OAS program, but will become a program of the Invention League. Veronica Lynagh will continue as Executive Director. At the center of this decision was how to best serve Ohio's students and to continue Invention Convention'shighstandards of teaching critical thinking and problem-solving skills, not to mention having fun!
Believe in Ohio - On May 7, 2016, Believe in Ohio held its 2nd Annual State Competition and 138 high school students were awarded \$509,000 in Ohio college scholarships and cash awards. For the 2015-2016 school year, more than 9,000 students participated statewide, which was a considerable increase from the 2,740 students in the 2014-2015 school year.

This fall, Believe in Ohio conducted STEM Commercialization and Entrepreneurship Forums in partnership with 13 different colleges and universities throughout Ohio. More than 2,200 high school and middle schoolstudents participated. Attendingstudents were introduced to innovative STEM topics and mentored on how STEM research could be developed into a business plan.

Believe in Ohio continues to impress students, teachers, and professionals from across Ohio. Mr. Hugh Bolton, Director of Commercialization for the Wright State Research Institute, recently commented, "As a function of my position, I have reviewed commercialization programs at universities across the country, and have also reviewed the Believe in Ohio program in depth. In my opinion, the Believe in Ohio program is one of the best programs of its kind I have seen and provides an excellent opportunity for students to explore interests in entrepreneurial activities early in their academic programs.”

State Science Day - What is the granddaddy of them all? No, not the Rose Bowl, but State Science Day! The 68th 
Annual SSD was hosted by The Ohio State University on May 14, 2016. More than 1,100 students in grades 5-12 competed for more than $\$ 600,000$ in scholarships and sponsored awards. State Science Day is sponsored by The Ohio State University, A merican Electric Power, The Ohio Environmental Education Fund, Ethicon Endo-Surgery, and the Battelle Memorial Institute.

The 69th Annual State Science Day will be held on Saturday, May 13, 2017 at the French Field House on the campus of The Ohio State University.

The Obio Journal of Science - Publishing scientific research since 1900, The Obio Journal of Science is celebrating a re-birth of interest among authors and devout readers alike. In 2016, the OJS re-established a ResearchGate journal impact (.64) and continues to receive and accept a record number of high quality manuscripts.

At year-end 2016, Dr. Michele Morrone (Ohio University, Professor of Health Science) stepped down as co-editor of The Obio Journal of Science. On behalf of the OAS Board of Trustees and OJS co-editor Dr. Jeffrey McKee (The Ohio State University, Professor of Anthropology), thank you Dr. Morrone for providing this much-needed lift duringyour tenure and for helping pave such a bright future.

Dr. Jeffrey McKee, will continue his work as Editor for The Obio Journal of Science.

Annual Meeting - The 2016 Annual Meeting was held at Ohio University on April 14th. A total of 23 universities and colleges were represented and was attended by more 250 professionals and students from all scientific disciplines. Many thanks to Ohio University and our local host, Dr. Michele Morrone for providing a perfect venue and supporting a great day research and fellowship.

The University of Cincinnati will host the 2017 Annual Meeting on April 8th. A total of 136 abstracts have been received and are currently being reviewed. There is a second call for abstracts opening from January 1 to February 27. This second call is for poster session only and is open to college students and faculty.

\section{Reflections of 2016 and a Vision for 2017 -}

After leading the Academy for more than $21 / 2$ years, Dr. Stephen McConoughey resigned in April as CEO to accept a position with the Allen Institute for Brain Science. During Steve's tenure, he greatly expanded Junior Academy programing and the Institutional Membership, which is responsible for doubling the Academy's members from 2014 through 2016.

It is inspiring and humbling for me to follow in Steve's path, but I have the good fortune of having a working relationship with him and former CEO, Dr. Lynn Elfner who both continue to generously share their experiences while providing me the support for growing new ideas and the courage to challenge traditional processes.

While 2016 saw tremendous growth in programing, the main goal for 2017 will be establishing new ways to create a more informed and engaged membership. This means improving and expanding communications and providing more opportunities for members to take an active role on OAS Councils and Committees. These working bodies are intended to facilitate linkages among government, industry, business, education, and the Academy.

If you are interested in learning more, please contact me any time to discuss these opportunities, or for additional information, please visit the Academy's website at www. ohiosci.org.

Enjoy reading Volume 116 (2).

Sincerely,

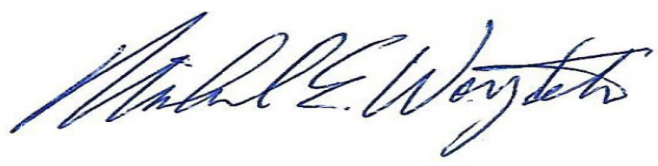

Michael E. Woytek

CEO 